\title{
Dwarf spurge (Euphorbia exigua L.) in the Cieszyńskie Foothills - present state and degree of severity
}

\author{
Wilczomlecz drobny (Euphorbia exigua L.) na Pogórzu Cieszyńskim - stan \\ aktualny i stopień zagrożenia
}

\author{
Eugeniusz Chwastek ${ }^{1}$, Robert Idziak ${ }^{2 *}$, Hubert Waligóra² ${ }^{2}$ Piotr Szulc ${ }^{2}$
}

\section{Summary}

The studies on segetal communities and weed species occurring within them have been conducted in Cieszyńskie Foothills since the first decade of the 21st century. There are soils with a high content of limestone, which allows to format calcophilic communities from Caucalidionlappulae alliance. One of the species representing this association is archeophyte dwarf spurge (Euphorbia exigua L.). In Cieszyńskie Foothills it has been recorded since the 19th century and in various periods of the 20th century as well in most crops, such as spring cereal mixtures, spring barley, spring and winter wheat, occasionally in maize and potato. Changes in crops structure abandonment of root crops in favour of maize and winter rape or changes in cereal cultivation (new technologies, herbicides) lead to decrease in potential habitats for dwarf spurge.

Key words: segetal communisties, calcophilic species, cereals, rendzinas soil

\section{Streszczenie}

Badania zespołów segetalnych i występujących w nich gatunków chwastów są prowadzone na Pogórzu Cieszyńskim od pierwszej dekady 21. wieku. Występują tu gleby o dużej zawartości wapieni (margle i łupki cieszyńskie), co pozwala na kształtowanie się kalcyfilnych zespołów ze związku Caucalidionlappulae. Jednym z gatunków charakterystycznych dla tego związku jest archeofit - wilczomlecz (ostromlecz) drobny (Euphorbia exigua L.). Na Pogórzu Cieszyńskim notowany był już od końca 19. wieku oraz w różnych okresach 20. wieku w większości upraw rolniczych, tj. mieszankach zbóż jarych, jęczmieniu jarym, pszenicy jarej, pszenicy ozimej, sporadycznie w kukurydzy i ziemniaku. Zmiany w strukturze zasiewów - zaniechanie upraw roślin okopowych na rzecz zwiększających się powierzchni upraw kukurydzy na ziarno i rzepaku ozimego oraz zmiany w zasiewach zbóż (nowe technologie i stosowane herbicydy) powodują zmniejszanie się potencjalnych siedlisk dla tego gatunku.

Słowa kluczowe: zbiorowiska segetalne, gatunki wapieniolubne, uprawy zbóż, gleby rędzinowe

\author{
III Liceum Ogólnokształcące im. Stanisława Wyspiańskiego \\ Elfów 62, 43-100 Tychy \\ 2Uniwersytet Przyrodniczy w Poznaniu \\ Dojazd 11, 60-632 Poznań \\ *corresponding author: robert.idziak@up.poznan.pl \\ ORCID: 0000-0002-1621-9184
}




\section{Wstęp / Introduction}

Wilczomlecz (ostromlecz) drobny (Euphorbia exigua L.) jest jednym z nielicznych archeofitów w obrębie rodzaju Euphorbia dotyczących flory Polski. Na terenie Pogórza Cieszyńskiego jego obecność stwierdzano już w końcu 19. wieku (Wimmer 1857; Kolbenheyer 1862; Oborny 1885; Formanek 1887) oraz na początku 20. wieku (Schube 1903, 1904), a także w drugiej połowie 20. wieku (Pelc 1967; Buława 1976; Zając 1989), co potwierdziły badania przeprowadzone w ostatnich latach (Chwastek 2008; Naks 2010).

Wilczomlecz drobny jest drobną, nieowłosioną rośliną o wysokości do $20 \mathrm{~cm}$, z łodygą zwykle rozgałęzioną od nasady, rzadko pojedynczą, zakończoną wierzchotką trójramienną, rozgałęziająca się 2-3-krotnie. Liście tego gatunku są siedzące, równowąskie, tępe, o długości 1,5-2 cm i szerokości 1,5-2 mm, a miodniki w kształcie jajowate z dwoma białawymi rożkami. Torebki są nagie, gładkie, $2 \mathrm{~mm}$ długie, tak samo grube i zawierają nasiona o długości 1,2-1,5 mm, szerokości 0,9-1,1 mm, które są dość grube, około 0,7-0,9 mm, jajowate, szare lub brunatne, z nieregularnymi guzkami barwy szarej. Gatunek ten kwitnie w okresie letnim, od czerwca do września (Jasiewicz 1992).

Wilczomlecz drobny preferuje gleby zasadowe. Obserwowany jest głównie w uprawach różnych roślin rolniczych, ale spotykany jest także na ugorach (wczesna wiosna) oraz na świeżych poboczach i skarpach dróg. Jest gatunkiem charakterystycznym dla związku Caucalidionlappulae, w obrębie rzędu Centauretaliacyani i klasy Stellarieteamediae (Matuszkiewicz 2008), pochodzącym z rejonu śródziemnomorskiego, sięgającym po części północy Europy. Jego obecność, w wyniku zawleczenia przez ludzi, stwierdza się również w Australii i Ameryce Północnej (Smith i Tutin 1968). W Polsce notowany jest na terenie całego kraju, choć zdecydowanie najczęściej na Nizinie Śląskiej (Penderi i Szczęśniak 2011) i Pogórzu Śląskim (Pogórze Cieszyńskie) (Naks 2005; Chwastek 2008). Wilczomlecz drobny w skali kraju nie jest gatunkiem zagrożonym (Zając i wsp. 2009), jedynie na Opolszczyźnie został uznany jako gatunek bliski zagrożenia (Nowak i wsp. 2008), a na Dolnym Śląsku jako gatunek słabo zagrożony (Kącki i wsp. 2003).

Celem badań była ocena występowania gatunku wilczomlecz drobny (Euphorbia exigua L.) na polach uprawnych Pogórza Cieszyńskiego.

\section{Materiały i metody / Materials and methods}

Badania dotyczące występowania wilczomlecza drobnego przeprowadzone w latach 2005-2018 w swych założeniach polegały na penetracji upraw rolniczych Pogórza
Cieszyńskiego, w celu odszukania stanowisk występowania tego gatunku oraz ustalenia zespołów segetalnych, w których był notowany. Zdjęcia fitosocjologiczne o powierzchni $100 \mathrm{~m}^{2}$ każde, wykonano z zastosowaniem powszechnie stosowanej metody Brauna-Blanqueta, przyjmując że 5 to liczba osobników dowolna, pokrycie powierzchni zdjęcia powyżej 75\%; 4 - liczba osobników dowolna, pokrycie 50-75\%; 3 - liczba osobników dowolna, pokrycie 25-50\%; 2 - liczba osobników duża, pokrycie 5-25\%; 1 - liczba osobników 5-50, pokrycie $>5 \%$; + - liczba osobników niewielka (2 do 5), pokrycie $<5 \%$; r - liczba osobników bardzo mała - 1 okaz (Pawłowski 1972; Woźniak i Soroka 2015). W tym czasie wykonano kilkaset zdjęć fitosocjologicznych, W różnych uprawach (mieszanki zbóż jarych, pszenica jara, owies, zboża ozime - jęczmień i pszenica, kukurydza, ziemniak), każde w okresie czerwiec-sierpień, w obrębie powiatów (bielsko-bialski i cieszyński), w 27 miejscowościach. W opracowaniu wykorzystano 54 zdjęcia fitosocjologiczne. Typy, podtypy gleb i kompleksy glebowe określano na podstawie mapy numerycznej w skali 1 : 75 000, opracowanej w Instytucie Uprawy Nawożenia i Gleboznawstwa - Państwowym Instytucie Badawczym, na podstawie analogowej mapy glebowo-rolniczej w skali 1 : 25 000. Nazewnictwo roślin przyjęto na podstawie Flovering plants and pteridiophytes of Poland. A checklist za Mirkiem i wsp. (2002). Syntaksonomię fitosocjologiczną dostosowano do najnowszego opracowania syntetyczno-systematycznego Matuszkiewicza (2001).

\section{Wyniki i dyskusja / Results and discussion}

Badania związane $\mathrm{z}$ występowaniem gatunków segetalnych w uprawach rolniczych na Pogórzu Cieszyńskim w omawianym okresie pozwoliły na ustalenie miejsc występowania E. exigua - wilczomlecza drobnego, dokładnie w 22 miejscowościach: Bażanowice, Bielowicko, Cieszyn Krasna, Cisownica, Godziszów, Goleszów, Górki Małe, Gumna, Hażlach, Iłownica, Iskrzyczyn, Kiczyce, Kisielów, Kowale, Kozakowice, Krasna, Leszna Górna, Lipowiec, Łączka, Ogrodzona, Pierściec, Puńców, Roztropice, Simoradz, Ustroń-Hermanice, Wieszczęta, Wiślica, Zamarski, zlokalizowanych w następujących kwadratach ATPOL (Komsta 2016) - kwadraty o boku $2 \times 2$ km: DG 0003, DG 0004, DG 0012, DG 0014, DG 0023, DG 0024, DG 0101, DG 0103, DG 0104, DG 0110, DG 0111, DG 0112, DG 0120, DG 0130, DF 8144, DF 9032, DF 9033, DF 9043, DF 9044, DF 9103, DF 9104, DF 9111, DF 9112, DF 9114, DF 9120, DF 9023, DF 9130, DF 9140, DF 9141, DF 9142, DF 9210 (tab. 1).

Wilczomlecz drobny na Pogórzu Cieszyńskim był notowany często w większości upraw rolniczych, tj. mieszankach zbóż jarych, jęczmieniu jarym, pszenicy jarej, pszenicy ozimej oraz sporadycznie w uprawach kukurydzy i ziemnia- 
Tabela 1. Miejsca występowania wilczomlecza drobnego - miejscowości i kwadraty ATPOL

Table 1. Locations of occurrence of dwarf spurge - locality and ATPOL squars

\begin{tabular}{|c|c|}
\hline $\begin{array}{l}\text { Miejscowość } \\
\text { Location }\end{array}$ & $\begin{array}{l}\text { Kwadrat ATPOL } \\
\text { ATPOL squar }\end{array}$ \\
\hline Bażanowice & DG 0004, DG 0014 \\
\hline Bielowicko & DF 9210 \\
\hline Cieszyn Krasna & DG 0003 \\
\hline Cisownica & DG 0120 \\
\hline Godziszów & DF 9140 \\
\hline Goleszów & DG 0111 \\
\hline Górki Małe & DG 0104 \\
\hline Gumna & DF 9043 \\
\hline Hażlach & DF 9023 \\
\hline Iłownica & DF 8240 \\
\hline Iskrzyczyn & DF 9120 \\
\hline Kiczyce & DF 9112 \\
\hline Kisielów & DF 9141 \\
\hline Kowale & DF 9114 \\
\hline Kozakowice & DG 0101, DG 0112 \\
\hline Leszna Górna & DG 0024, DG 0130 \\
\hline Lipowiec & DG 0103, DG 9104 \\
\hline Łączka & DF 9130 \\
\hline Ogrodzona & DF 9044 \\
\hline Pierściec & DF 9103, DF 9104 \\
\hline Puńców & DG 0012, DD 0013, DG 0023 \\
\hline Roztropice & DF 8144, DF 9104, DF 9114 \\
\hline Simoradz & DF 9111, DF 9120 \\
\hline Ustroń-Hermanice & DF 9142 \\
\hline Wieszczęta & DF 9114 \\
\hline Wiślica & DF 9111, DF 9112 \\
\hline Zamarski & DF 9032, DF 9033, DF 9043 \\
\hline
\end{tabular}

ka. Występowanie tego taksonu odnotowano w dziesięciu zespołach segetalnych (tab. 2). W niektórych z nich - wapieniolubnych, osiągał wysokie wartości względem ilościowości i towarzyskości. W zespołach Vicie tumtetraspermae (V.t. typicum, V.t. sperguletosum) wilczomlecz drobny występował nielicznie, jedynie w V.t. delphinietosum - kalcyfilna postać $V$. tetraspermae - licznie zaznaczył swą obecność. W pozostałych wapieniolubnych zespołach związku Caucalidionlappulae widoczny jest znaczny wzrost udziału omawianego gatunku w składzie zbiorowisk chwastów. Obfite występowanie E. exigua zaznacza się w zespołach Lathyro-Melandrietumnoctiflori (oba warianty - typowy i zubożały), gdzie osiąga maksymalne wartości 1.2 oraz 2.3 , a także w Geranio-Silenetumgallicae - 2.2. Wilczomlecz drobny zdecydowanie najczęściej obserwowany był w płatach Kic- kxietumspuriae - na jednej z powierzchni badawczych osiągając postać facji (3.4). Analizowany gatunek odnotowany został również w Silenoinflatae-Linarietumminoris (+.2). W płatach Lamio-Veronicetumpolitae i Oxalido-Chenopodietumpolyspermii (w zbożach) obecność E. exigua była podobna, jak w zespołach Vicie tumtetraspermae typicum i V.t. sperguletosum $(+)$.

Euphorbia exigua na Pogórzu Cieszyńskim preferuje gleby brunatne wyługowane (,śliny cieszyńskie”), rędziny i pseudobielicowe, $\mathrm{z}$ charakterystycznymi dla tego terenu kompleksami glebowymi - pszennym górskim oraz owsiano-ziemniaczanym górskim. Gleby brunatne tego typu, tzw. „krzosy” (Lazar 1962) wytworzone zostały z łupków marglistych oraz wapieni marglistych i występują na większości obszaru Pogórza Cieszyńskiego (szczególnie w jego południowo-zachodniej części). Odczyn tych gleb oscylował od $\mathrm{pH}$ na poziomie 5,6 do 7,1 . Powierzchnia upraw wynosiła od 0,1 do 7,5 ha. Nachylenie pól wahało się od 2 do $14^{\circ}$. Ekspozycja badanych powierzchni nawiązywała do kierunków południowych (najczęściej S, rzadziej SW i SE). Uprawy, w których stwierdzono występowanie E. exigua wykazywały znaczne zachwaszczenie (średnio 25 gatunków roślin ze wszystkich badanych powierzchni).

Systematyka zespołów segetalnych, w których stwierdzono obecność E. exigua, za Matuszkiewiczem (2008) przedstawia się następująco:

Klasa (Cl.) Stellarieteamediae

Rząd (O.) Centauretaliacyani

Związek (All.): Aperionspicae-venti

Zespół (Ass.):

Vicietumtetraspermaesperguletosum

Zespół (Ass.):

Vicietumtetraspermaetypicum

Zespół (Ass.):

Vicietumtetraspermaedelphinietosum

Związek (All.): Caucalidionlappulae

Zespół (Ass.):

Lathyro-Melandrietumnoctiflori wariant typowy

Zespół (Ass.):

Lathyro-Melandrietumnoctiflori wariant zubożały

Zespół (Ass.):

Geranio-Silenetumgallicae

Zespół (Ass.):

Kickxietumspuriae

Zespół (Ass.):

Silenoinflatae-Linarietumminoris

Rząd (O.) Polygono-Chenopodietalia

Związek (All.): Polygono-Chenopodion

Zespół (Ass.):

Lamio-Veronicetumpolitae

Zespół (Ass.):

Oxalido-Chenopodietumpolyspermii-w zbożach. 


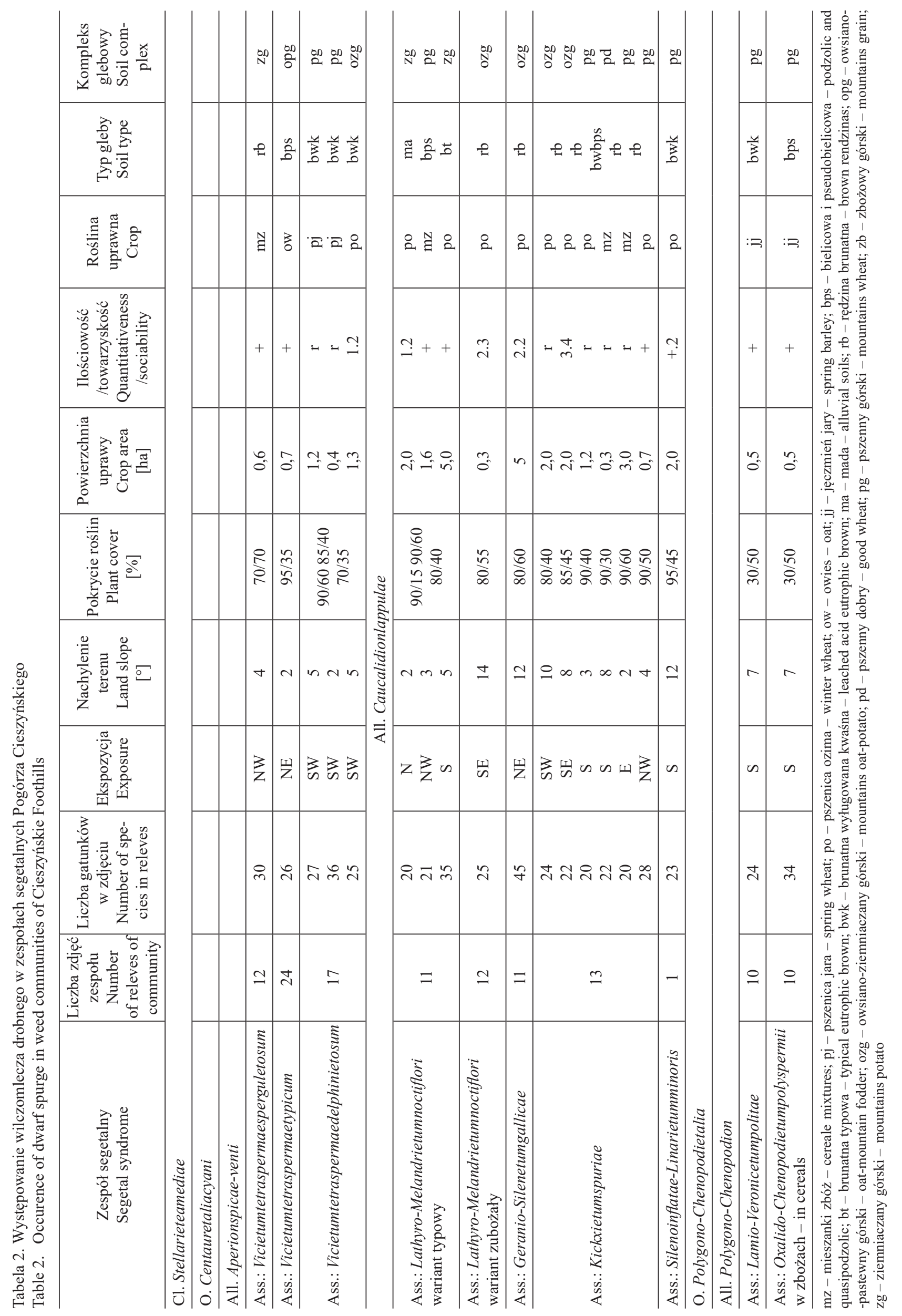




\section{Wnioski / Conclusions}

1. Wilczomlecz drobny (E. exigua) na terenie Pogórza Cieszyńskiego spotykano przede wszystkim w kalcyfilnych zespołach ze związku Caucalidionlappulae.

2. Najczęściej i najobficiej E. exigua występował w zespole Kickxietumspuriae.

3. Aktualnie na Pogórzu Cieszyńskim E. exigua występuje stosunkowo często, szczególnie w południowo-zachodniej części regionu.
4. Zagrożeniem dla występowania E. exigua mogą być zmiany w strukturze zasiewów, głównie zwiększający się udział kukurydzy i rzepaku, bowiem w tych gatunkach E. exigua występuje sporadycznie.

5. Obecność E. exigua w zespole Silenoinflatae-Linarietumminoris, w jedynym odnotowanym płacie tego zespołu, wymaga dalszych badań potwierdzających jego występowanie na Pogórzu Cieszyńskim.

\section{Literatura / References}

Buława W. 1976. Flora i zbiorowiska roślinne wyrobisk pokamieniołomowych wapiennych na Pogórzu Cieszyńskim. Uniwersytet Łódzki (manuskrypt).

Chwastek E. 2008. Zbiorowiska segetalne Pogórza Cieszyńskiego [online]. Uniwersytet Śląski, Katowice, 149 ss. https://sbc.org.pl/ Content/12088/doktorat2900.pdf [dostęp: 14.11.2019].

Formanek E. 1887. Kvetna Moravy a rakouskeho Šlezska. Nakl. Spisovatelovym, Brno, s. 1474.

Jasiewicz A. (red.). 1992. Flora Polski. Rośliny naczyniowe. T. III. Instytut Botaniki im. W. Szafera, Polska Akademia Nauk, Kraków, s. $149-150$.

Kącki Z., Dajdok Z., Szczęśniak E. 2003. Czerwona lista roślin naczyniowych Dolnego Śląska. s. 9-65. W: Zagrożone gatunki flory naczyniowej Dolnego Śląska (Z. Kącki, red.). Instytut Biologii Roślin, Uniwersytet Wrocławski, PTPP Pro Natura, Wrocław.

Kolbenhayer K. 1982. Vorarbeitenzur Flora von Teschen und Bielitz. Verhandlungen der Zoologisch-Botanischen Gesellschaft in Wien 12.

Komsta Ł. 2016. Rewizja matematyczna siatki geobotanicznej ATPOL - propozycja algorytmów konwersji współrzędnych. [ATPOL geobotanical grid revisited - a proposal of coordinate conversion algorithms]. Agronomy Science 71 (1): 31-37.

Lazar J. 1962. Gleby województwa katowickiego. Śląski Instytut Naukowy, Państwowe Wydawnictwo Rolnicze i Leśne, Warszawa.

Matuszkiewicz W. 2001. Przewodnik do oznaczania zbiorowisk roślinnych Polski. Wydawnictwo Naukowe PWN, Warszawa, 537 ss.

Matuszkiewicz W. 2008. Przewodnik do oznaczania zbiorowisk roślinnych Polski. Wydawnictwo Naukowe PWN, Warszawa, 99 ss.

Mirek Z., Piękoś-Mirkowa H., Zając A., Zając M. 2002. Flowering plants and pteridiophytes of Poland. A checklist. Series: Biodiversity of Poland, Vol. 1. Instytut Botaniki im. W. Szafera, Polska Akademia Nauk, Kraków, 442 ss. ISBN 83-85444-83-1.

Naks P. 2010. Flora Pogórza Cieszyńskiego i północnej części Kotliny Ostrawskiej oraz jej aspekty geobotaniczne. Zakład Taksonomii Roślin i Fitogeografii. Uniwersytet Jagielloński, Kraków. Manuskrypt pracy doktorskiej, 282 ss.

Nowak A., Nowak S., Spałek K. 2008. Red list of vascular plants of Opole province. Nature Journal 41: 141-158.

Oborny A. 1885. Flora von Mähren und Österr. Schlesien. 2. Commissionsverlag der k.k. Hof-Buchhandlung C. Winiker, Brünn, s. $761-1258$

Pawłowski B. 1972. Skład i budowa zbiorowisk roślinnych oraz metody ich badania. s. 237-268. W: Szata roślinna Polski, T. I (W. Szafer, K. Zarzycki, red.). Państwowe Wydawnictwo Naukowe, Warszawa.

Pelc S. 1967. Rośliny naczyniowe Pogórza Cieszyńskiego. Rocznik Naukowo-Dydaktyczny. WSP w Krakowie 28: 109-208.

Pender K., Szczęśniak E. 2011. Euphorbia exigua (Euphorbiaceae) na Dolnym Śląsku - stan aktualny i stopień zagrożenia. Acta Botanica Silesiaca, Supplementum 1: 120-122.

Schube T. 1903. Die Verbreitung der Gefässpflanzen in Schlesien preussischen und österreichischen Anteils. R. Nischkowsky Verl., Breslau, 361 ss.

Schube T. 1904. Flora von Schlesien preussischen und österreichischen Anteils. W.G. Korn Breslau, 456 ss.

Smith A.R., Tutin T.G. 1968. Euphorbia. s. 213-216. W: Flora Europaea. Vol. 2 (T.G. Tutin, V.H. Heywood, N.A. Bureges, D.M. Moore, D.H. Valentine, S.M. Walters, D.A. Webb, red.). Rosaceaeto Umbelliferae-Cambridge University Press, Cambridge.

Wimmer F. 1857. Flora von Schlesien. Verl. Von F. Hirt, Breslau, 695 ss.

Woźniak A., Soroka M. 2015. Syntaksonomiczna ocena zbiorowisk chwastów w zasiewach żyta (Secale cereale L.) na polach ukraińskiego Roztocza. [Syntaxonomic evaluation of weed communities in rye in the Ukrainian Roztocze]. Fragmenta Agronomica 32 (2): 97-110.

Zając M. 1989. Flora południowej części Kotliny Oświęcimskiej i Pogórza Śląskiego. [Flora of the southern part of the Oświęcim Basin and Silesian Foothills]. Zeszyty Naukowe Uniwersytetu Jagielońskiego, Prace Botaniczne 19, 199 ss.

Zając M., Zając A., Tokarska-Guzik B. 2009. Extinct and endangered archaeophytes and the dynamics of their diversity in Poland. Biodiversity Research and Conservation 13 (1): 17-24. DOI: 10.2478/v10119-009-0004-4 